\title{
PENGEMBANGAN SISTEM INFORMASI SARANA DAN PRASARANA DI UNIVERSITAS TEKNOLOGI SUMBAWA (UTS) BERBASIS WEB
}

\author{
Irwan Sakti Pratama ${ }^{1)}$, Nawassyarif ${ }^{2)^{*}}$, Jannatun Aliyah ${ }^{3)}$ \\ 1) Mahasiswa Informatika Universitas Teknologi Sumbawa \\ 2), 3) Dosen Informatika Universitas Teknologi Sumbawa \\ nawassyarif@uts.ac.id 2), irwansaktipratama2@gmail.com 1), jannatun.aliyah@uts.ac.id ${ }^{3)}$
}

\begin{abstract}
Abstrak
Universitas Teknologi Sumbawa (UTS) merupakan salah satu perguruan tinggi di Indonesia yang terletak di pulau Sumbawa Provinsi Nusa Tenggara barat. Sebagai intitusi pendidikan, dalam menunjang proses operasionalnya diperlukannya sarana dan prasarana yang memadai, Maka dibentuklah biro Sarana dan Prasarana (SARPRAS) bertugas untuk mendata setiap sarana dan prasarana yang dimiliki oleh UTS dengan cara memberikan nomor identitas, jumlah stok, penempatan, peminjaman dan pengembalian, pengadaan sampai dengan mutasi. Selama ini pihak sarpras masih melakukan pendataan dengan cara mengetikan dengan tools Microsoft office yang dimana sering ditemukan beberapa ketidak cocokan antara data dengan aslinya dan terdapat data yang. Penelitian ini bertujuan untuk membangun sistem pengelolaan data inventaris UTS berbasis Web. Dalam pengembangannya menggunakan metode waterfall dengan metode pengumpulan data kualitatif bersifat deskriprtif. Pengembangan sistem menggunakan bahasa pemrograman PHP, JavaScript, CodeIgniter, Jquery dan MySQL dengan pengujian perangkat lunak menggunakan black-box. Dari penelitian yang dilakukan bahwa sistem dapat membantu proses pengelolaan data inventaris di biro SARPRAS UTS dengan penilaian baik yang menandakan bahwa sistem tersebut layak untuk digunakan.
\end{abstract}

Kata Kunci: Sistem Informasi, Sarana dan Prasarana, Inventaris, Web, CodeIgniter

\begin{abstract}
University Technology of Sumbawa (UTS) is one of the universities in Indonesia, located on Sumbawa Island in West Nusa Tenggara province. As educational institution, in supporting the process of operational needs and adequate infrastructure, then established the Bureau of Facilities and infrastructure (SARPRAS) to record every facility and infrastructure owned by UTS by providing Identity, placement, borrowing, procurement up to mutations. During this time, the Sarpras party is still logging in the Microsoft Office tools that are often found in some data inconsistency issues and there are similar data. This research aims to build a WEB-based data-management UTS inventory system. Its development uses waterfall method with qualitative data collection method. System development uses PHP, JavaScript, CodeIgniter, and MySQL programming languages with software testing using black-box. From the research conducted that the system can help the process of managing inventory data in the Bureau SARPRAS UTS with good judgment that indicates that the system is worth the use.
\end{abstract}

Keywords: information systems, facilities and infrastructure, inventory, WEB, CodeIgniter

\section{Pendahuluan}

Biro Sarana dan Prasarana di Universitas Teknologi Sumbawa bertugas untuk mendata setiap sarana dan prasarana yang dimiliki oleh UTS dengan cara memberikan nomor identitas, jumlah stok, penempatan, peminjaman dan pengembalian, pengadaan, sampai dengan mutasi. Dalam hal ini maka dibutuhkan sebuah sistem yang mampu menunjang hal tersebut. selama ini pihak sarpras masih melakukan pendataan dengan cara mengetikan di word maupun excel yang dimana sering ditemukan beberapa masalah seperti data yang tidak cocok antara data dengan aslinya, terdapat data yang sama untuk inventaris yang sama, sampai dengan pemberian identitas yang masih tidak konsisten.

Permasalahan tersebut sudah pernah diangkat oleh Eva Juliani Informatika 2013 yang dimana telah menghasilkan solusi dengan cara dibuatkan sebuah sistem informasi sarana dan prasarana. Namun dari solusi yang diberikan tersebut masih ada beberapa point yang bisa dikembangkan seperti penambahan fitur penghapusan dan peminjaman $^{[1]}$. Dari pihak Sarana dan Prasarana (SARPRAS) membutuhkan pengembangan pada pemberian identitas sesuai dengan ketentuan yang sudah dibuat.

Solusi yang sudah pernah diberikan oleh peneliti sebelumnya belum mampu menunjang 
semua fungsi dan tujuan dari pihak SARPRAS. Sehingga diperlukan pengembangan Sistem Informasi Sarana dan Prasarana di Universitas Teknologi Sumbawa (UTS) berbasis Web untuk menunjang pekerjaan sesuai fungsi dan tujuannya.

Berdasarkan latar belakang yang telah dipaparkan diatas, dapat diidentifikasi masalahnya sebagai berikut :

a. Perlu adanya penambahan fitur-fitur yang mampu menunjang fungsi dan tujuan SARPRAS.

b. Pemberian nomor identitas sarana dan prasarana sesuai prosedur SARPRAS.

Dengan demikian, dapat dibuat rumusan masalah yaitu bagaimana pengembangan yang dapat dilakukan untuk menunjang fungsi dan tujuan dari bagian SARPRAS UTS ?

Adapun batasan masalah yang akan dikerjakan adalah pengembangan sistem informasi sarana dan prasarana di Universitas Teknologi Sumbawa dari penelitian sebelumnya meliputi :

a. Penambahan fitur hapus prasarana

b. Penambahan fitur peminjaman dan pengembalian

c. Penambahan fitur jadwal ruangan

d. Memperbaiki logika penomoran (identitas) prasarana

e. Memperbaharui user interface sistem

f. Dikembangkan dengan menggunakan bahasa pemrograman $P H P$ dan $M Y S Q L$ sebagai sistem manajemen basis data

Adapun tujuan dari penelitian ini adalah untuk mengembangkan penelitian sebelumnya agar dapat mewadahi tempat penelitian dalam melakukan aktivitasnya. Dengan berhasilnya penelitian ini nantinya diharapkan mampu menunjang fungsi dan tujuan yang dimiliki oleh tempat penelitian yang dalam hal ini adalah bagian Sarana dan Prasarana (SARPRAS) Universitas Teknologi sumbawa.

\section{Tinjauan Pusataka}

Rancang bangun sistem informasi seperti sarana dan prasarana telah banyak dilakukan. Beberapa penelitian yang kurang lebih memiliki keterkaitan atau kesamaan seperti sistem informasi sarana dan prasarana berbasis web ini, antara lain Sistem Informasi Prasarana Berbasis Web studi kasus SD Negeri 1 Gatak Delanggu ${ }^{[2]}$ oleh Rotstaland Dito Soeharto Poetro tahun 2017. Penelitian tersebut menggunakan bahasa pemrograman PHP, HTML, serta database $M y S Q L$, selain itu penelitian ini dibangun menggunakan metode pengembangan perangkat lunak waterfall, dianalisis dan dirancang berorientasi objek menggunakan Unified Modeling Language (UML), dan diuji menggunakan metode black-box. Fitur-fitur yang dibangun dalam penelitian ini mampu menunjukkan fungsionalitas sistem tersebut dapat memanajemen prasarana yang ada seperti fitur login, menampilkan infromasi prasarana bangunan dan sebagainya, menambahkan data prasarana, serta mencetak laporan prasarana dalam bentuk PDF.

Dalam jurnal lain oleh Akhmad Sholikhin dan Berliana Kusuma ${ }^{[3]}$ Riasti tahun 2013 menggunakan bahasa pemrograman PHP dan Mysql dalam pembuatan sistemnya. Untuk perancangan sistemnya dijelaskan dengan flowchart alur sistem yang akan dibuat tanpa menggunakan metode perancangan seperti $D F D$ ataupun $U M L$. Sedangkat untuk fiturfitur yang tersedia pada sistem berupa login, data ruangan, dan data barang yang dapat dicetak lansung ke printer sebagai laporan.

Sementara penelitian mengenai sistem informasi pengelolaan sarana dan prasarana di universitas teknologi Sumbawa yang dilakukan oleh Eva juliani $^{[1]}$ tahun 2017 dalam menyelesaikan program studi S1 informatika di Universitas Teknologi Sumbawa. Penelitian tersebut menggunakan bahasa pemrograman $P H P$ dalam pembuatan sistem dan $M y S Q L$ sebagai basis datanya, selain itu dalam merancang sistem secara terstuktur menggunakan data flow diagram (DFD) dan menerapkan metode pengembangan perangkat lunak waterfall . Dalam penelitian ini Sistem yang dibuat merupakan sistem informasi pengelolaan sarana dan prasarana yang meliputi pengelolaan data inventaris atau barang, data jenis inventaris, data golongan, data subgolongan, data unit kerja, data ruangan, data pengajuan pengadaan inventaris, data persetujuan pengadaan inventaris, data pengadaan inventaris, data penempatan inventaris, data pindah/mutasi inventaris, dan data perawatan inventaris.

Perbedaan penelitian yang dilakukan oleh peniliti sekarang dibandingkan dengan peneliti sebelumnya adalah penelitian ini merupakan pengembangan dari penelitan yang dilakukan oleh Eva juliani pada paragraph 3 (tiga) dengan menambahkan beberapa fitur seperti peminjaman, jadwal ruangan, dan mengembangkan sistem yang sudah ada sebelumnya dengan memperbaharui tampilan, algoritma sistem, dan penambahan firut notifikasi melalui email bagi peminjam. Dibandingkan dengan penelitian lainnya (paragraph 1 dan 2 ) penelitian ini memiliki ruang lingkup yang luas dari segi fitur yang diberikan.

Menurut O'Brien (2005) ${ }^{[4]}$, sistem informasi adalah suatu kombinasi yang terorganisir dari people (orang), hardware (perangkat keras), software (perangkat lunak), computer networks (jaringan komputer), data communications (jaringan komunikasi), database (basis data) yang 
mengumpulkan, mengubah, dan mendistribusikan informasi di dalam suatu bentuk organisasi.

Seperti yang dikemukanan oleh Megasari (2014) $)^{[5]}$ Sarana dan prasarana merupakan salah satu sumber daya pendidikan yang perlu dan sangat penting dikelola dengan baik serta merupakan bagian yang tidak dapat dipisahkan dari manajemen pendidikan. Seperti gedung, tanah, perlengkapan administrasi sampai pada sarana yang digunakan langsung dalam proses belajar mengajar di kelas.

Menurut Rosa dan Shalahuddin (2018) ${ }^{[6]}$, UML (Unified Modeling Language) adalah salah satu standar bahasa yang banyak digunakan di dunia industri untuk mendefinisikan requirement, membuat analisa dan desain, serta menggambarkan arsitektur dalam pemrograman berorintasi objek. Dalam penelitian ini menggunakan 4 (empat) macam diagram yaitu :

\section{1) Use Case Diagram}

Use case diagram merupakan pemodelan untuk kelakuan (behavior) sistem informasi yang akan dibuat. Use case mendeskripsikan sebuah interaksi antara satu atau lebih aktor dengan sistem informasi yang akan dibuat. Secara kasar, use case digunakan untuk mengetahui fungsi apa saja yang ada di dalam sebuah sistem informasi dan siapa saja yang berhak menggunakan fungsifungsi itu.

\section{2) Activity Diagram}

Activity diagram menggambarkan workflow (aliran kerja) atau aktivitas dari sebuah sebuah sistem atau proses bisnis atau menu yang ada pada perangkat lunak. Yang perlu di perhatikan disini adalah bahwa diagram aktivitas menggambarkan aktivitas sistem bukan apa yang dilakukan aktor, jadi aktivitas yang dapat dilakukan oleh sistem.

\section{3) Sequence Diagram}

Sequence diagram menggambarkan kelakuan objek pada use case dengan mendeskripsikan waktu hidup objek dengan massage yang dikirimkan dan diterima antar objek. Oleh karena itu untuk menggambarkan diagram sekuen maka harus diketahui objek-objek yang terlibat dalam sebuah use case beserta metode-metode yang dimiliki kelas yang diinstansiasi menjadi objek itu.
Membuat diagram sekuen juga dibutuhkan untuk melihat skenario yang ada pada use case.

4) Class Diagram

Class diagram menggambarkan struktur sistem dari segi pendefinisian kelas-kelas yang akan dibuat untuk membangun sistem. Kelas memiliki apa yang disebut atribut dan method atau operasi. Atribut merupakan variablevariabel yang dimiliki oleh suatu kelas, sedangkan method atau operasi adalah fungsi-fungsi yang dimiliki oleh suatu kelas.

Menurut Ladjamudin (2006), flowmap $^{[7]}$ adalah bagan- bagan yang mempunyai arus yang menggambarkan langkah-langkah penyelesaian suatu masalah. Flowmap merupakan cara penyajian dari suatu algoritma.

Menurut Pressman (2015), model waterfall $^{[8]}$ adalah model klasik yang bersifat sistematis, berurutan dalam membangun software. Nama model ini sebenarnya adalah "Linear Sequential Model". Model ini sering disebut juga dengan "classic life cycle" atau metode waterfall. Model ini melakukan pendekatan secara sistematis dan berurutan. Disebut dengan waterfall karena tahap demi tahap yang dilalui harus menunggu selesainya tahap sebelumnya dan berjalan berurutan. Berikut tahapan metode waterfall yang dilakukan pada pengembangan perangkat lunak :

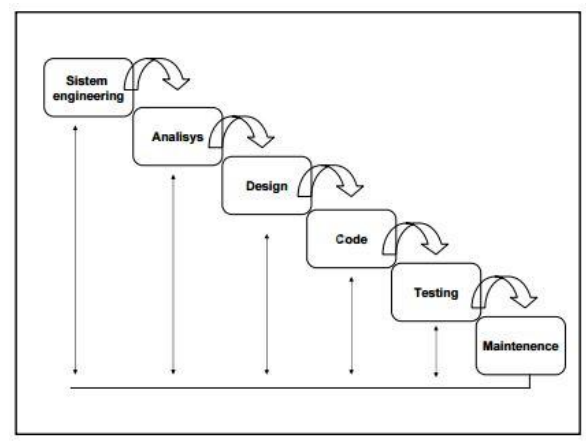

a. $M Y S Q L$

Menurut Arief (2011), MySQL ${ }^{[9]}$ adalah salah satu jenis database server yang sangat terkenal dan banyak digunakan untuk membangun aplikasi web yang menggunakan database sebagai sumber dan pengolahan datanya. 
Menurut Shalahuddin dan Rosa (2018), black box ${ }^{[6]}$ testing adalah menguji perangkat lunak dari segi spesifikasi fungsional tanpa menguji desain dan kode program. Pengujian dimaksudkan untuk mengetahui apakah fungsi-fungsi, masukan, dan keluaran dari perangkat lunak sesuai dengan spesifikasi yang dibutuhkan. Pengujian kotak hitam dilakukan dengan membuat kasus uji yang bersifat mencoba semua fungsi dengan memakai perangkat lunak apakah sesuai dengan spesifikasi yang dibutuhkan. Kasus uji yang dibuat untuk melakukan pengujian black box testing harus dibuat dengan kasus benar dan kasus salah.

\section{METODOLOGI PENELITIAN}

Dalam melakukan penelitian ini penulis menggunakan metode penelitian yang dibagi menjadi 2 (dua) metode yaitu, metode pengumpulan data dan metode pengembangan perangkat lunak sebagai berikut :

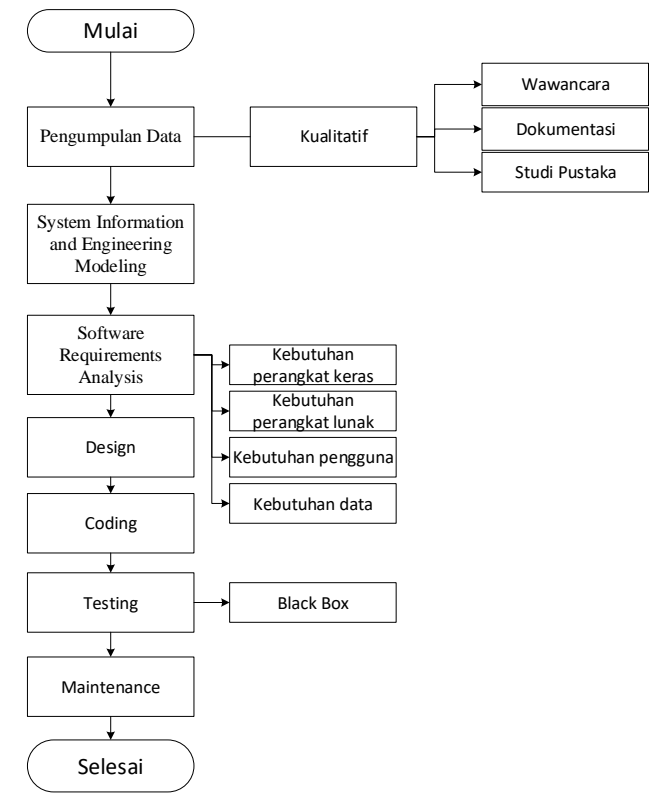

\section{Metode Pengumpulan Data}

Metode pengumpulan data merupakan teknik atau cara untuk memperoleh data yang dibutuhkan dalam proses penelitian. Dalam hal ini, penulis menggunakan pendekatan kualitatif deskriptif. Adapun teknik dalam pengumpulan data yaitu :

\section{a. Wawancara}

Wawancara adalah metode pengumpulan data yang dilakukan melalui tatap muka dan tanya jawab antara peneliti dan narasumber. Pada penelitian ini, penulis melakukan wawancara secara tidak terstruktur kepada bagian sarana dan prasarana (SARPRAS) guna mengumpulkan informasi yang dibutuhkan terkait permasalahan yang diangkat.

b. Dokumentasi

Pada teknik dokumentasi ini data-data yang berhubungan dengan penelitian didapat dengan cara mengumpulkan datadata yang sudah ada di Univeristas Teknologi Sumbawa. Data-data tersebut berupa data sarana dan prasarana Universitas Teknologi Sumbawa.

\section{c. Studi Kepustakaan}

Studi kepustakaan merupakan metode pengumpulan data yang dilakukan dengan cara mengumpulkan data dan informasi yang relevan dengan topik atau masalah yang sedang diteliti. Informasi tersebut dapat diambil dari buku, literatur, jurnal ilmiah, testis, maupun dari internet. Dalam kasus ini, penulis mencoba untuk mencari dan mengumpulkan referensi dari buku, jurnal ilmiah, skripsi sebelumnya, maupun internet yang sesuai dengan topik penelitian sebagai bahan pendukung penelitian.

\section{Metode Pengembangan Perangkat Lunak}

Berdasarkan model waterfall menurut Pressman 2015, maka tahapan-tahapan pengembangan perangkat lunaknya yaitu :

a. System Information and Engineering Modeling

Pada tahap ini peneliti akan mengumpulkan kebutuhan informasi yang akan diterapkan kedalam sistem. Kebutuhan tersebut diperoleh melalui proses wawancara kepada narasumber yang terkait, mengumpulkan dokumen terkait, serta melalui proses studi kepustakaan.

b. Software Requirement Analysis

Setelah mengumpulkan kebutuhan yang ada di sistem secara lengkap, kemudian dilanjutkan ke tahap analisis yang akan menggambarkan bagaimana sistem tersebut berjalan.

\section{c. Design}

Pada tahap desain, kebutuhan yang telah dianalisis sebelumnya, selajutnya direpresentasikan kedalam bentuk blueprint sistem yang akan dibangun, dengan mendesain rancangan sistem mulai dari Use Case Diagras, Activity Diagram, Class 
Diagram, Squence Diagram, dan perancangan lainnya.

d. Coding

Melakukan tahap pembuatan kode program sistem informasi sarana dan prasarana yang akan dibangun sesuai dengan hasil desain ke dalam kode atau bahasa yang dimengerti oleh mesin komputer dengan menggunakan bahasa pemrograman $P H P$ framework Codeigneiter dan MySQL.

\section{e. Testing/Verification}

Melakukan pengujian kebenaran logika dan fungsionalitas terhadap sistem yang dibangun untuk mengetahui apakah sistem yang dibuat telah sesuai dengan desainnya dan masih terdapat kesalahan atau tidak, serta disinilah akan diketahui kekurangankekurangan dari sistem informasi yang dibangun.

\section{f. Maintenance}

Perangkat lunak yang telah dibuat dan dikirim ke user tidak menutup kemungkinan mengalami perubahan. Perubahan bisa terjadi karena adanya kesalahan yang muncul dan tidak terdeteksi saat pengujian atau perangkat lunak harus beradaptasi dengan lingkungan baru. Oleh karena itu pada tahapan ini melakukan pemeliharaan perangkat lunak yang mengalami perubahan agar dapat berjalan dan sesuai dengan yang dirancang.

\section{Alat dan Bahan Penelitian}

Adapun alat dan bahan yang dibutuhkan dalam penelitian yaitu, kebutuhan perangkat dan kebutuhan data. Kebutuhan perangkat yang digunakan berupa perangkat keras (hardware), perangkat lunak (software), dan kebutuhan pengguna (user) dengan hak aksesnya sesuai dengan kebutuhan penelitian yang dilakukan. Sedangkan untuk kebutuhan data yang digunakan berupa data-data yang berkaitan dengan penelitian yang dilakukan.

\section{HASIL dAN PEMBAHASAN}

\section{Perancanan Sistem}

\section{a. UML}

1) Use Case

\section{a) Halaman Depan}

Halaman depan ini adalah halaman awal dari sistem yang dapat diakses oleh civitas akademika UTS secara keseluruhan. Gambaran aksi yang dapat dilakukan pada halaman ini adalah sebagai berikut :

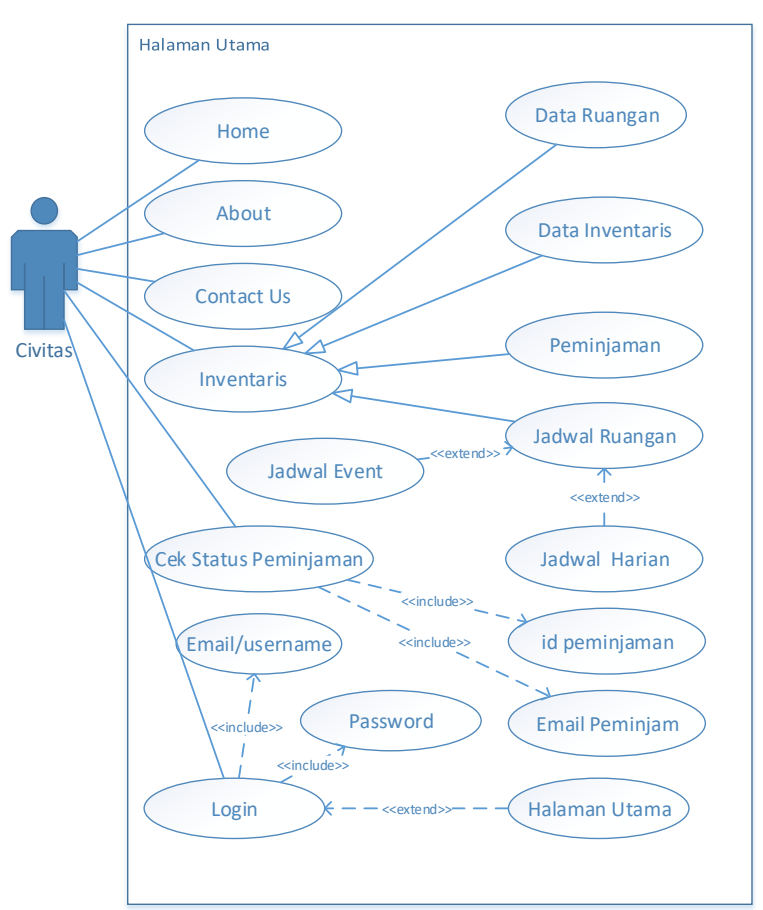

\section{b) Halaman Admin}

Halaman admin ini adalah halaman portal dari sistem yang dapat diakses oleh pengguna dengan hak akses SARPRAS, fakultas, dan WAREK II. Pada halaman ini pengguna yang telah disebutkan diatas, dapat mengelolah data-data yang berhubungan dengan data inventaris sesuai dengan hak akses yang diberikan bagi setiap pengguna. Adapun gambaran dari aksi pada halam ini dapat dilihat pada gambar berikut :

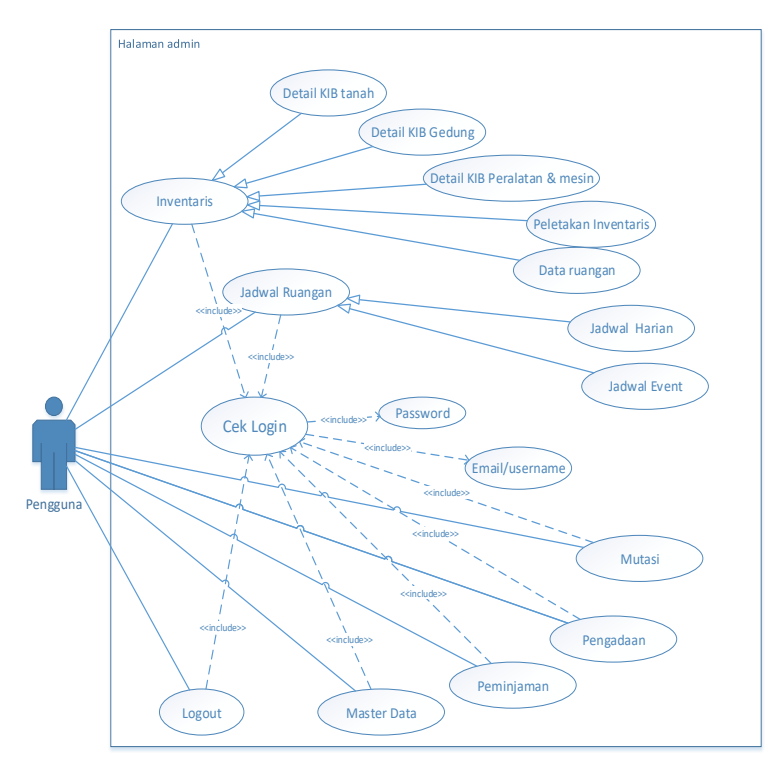




\section{2) Activity Diagram}

\section{a) Inventaris}

Proses ini menggambarkan mekanisme pengelolaan terhadap inventaris yang dimiliki. adapun gambaran dari proses tersebut digambarkan seperti gambar dibawah ini :

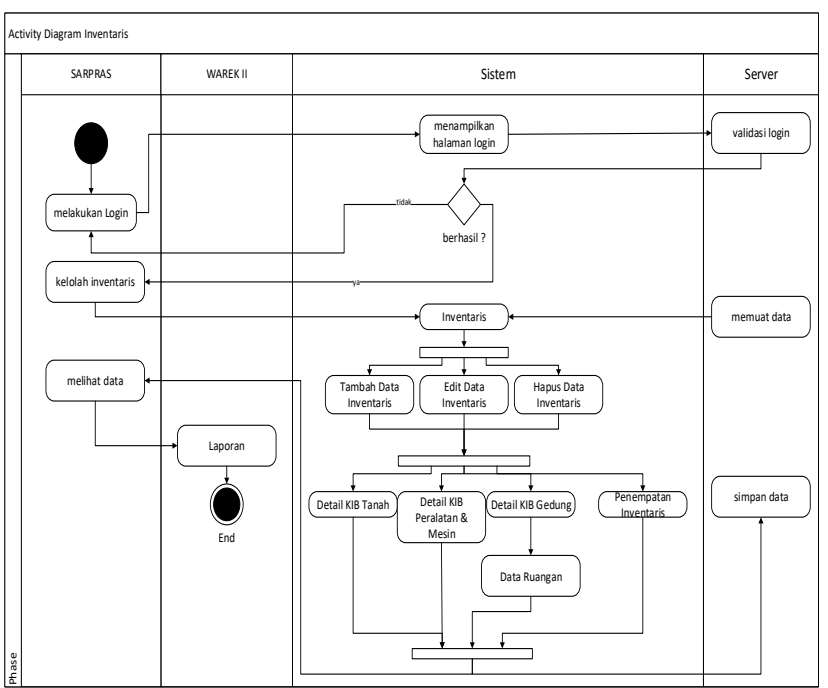

b) Mutasi

Proses ini menggambarkan langkah kerja dari proses mutasi inventaris dari tempat semula ke tempat selanjutnya. Hal ini dapat memudahkan biro SARPRAS dalam mendata persebaran inventaris yang dimiliki oleh UTS. Adapun gambaran dari proses tersebut dapat dilihat pada gambar dibawah ini :

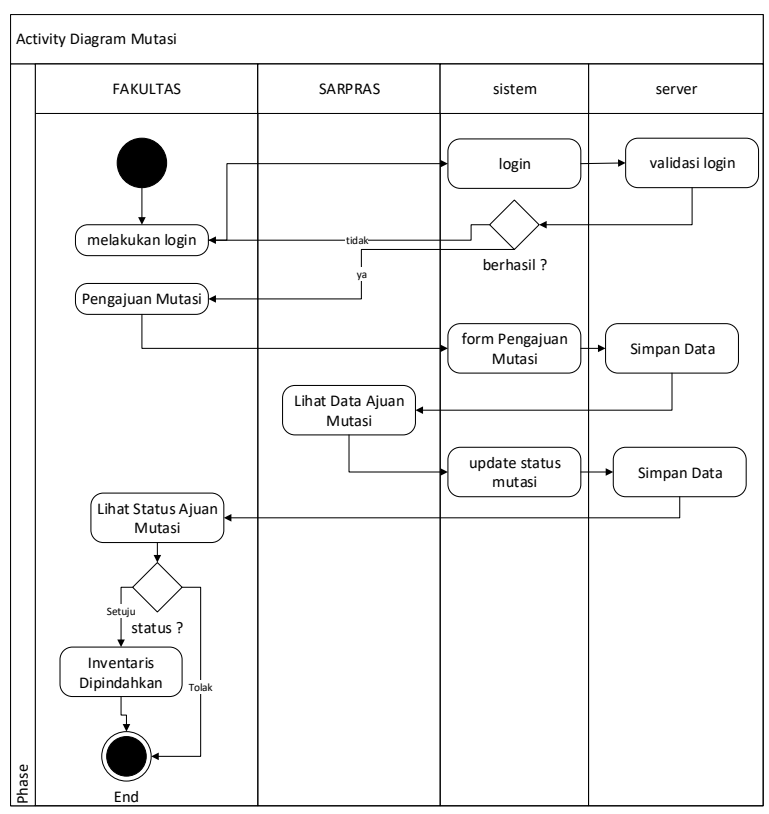

c) Jadwal Ruangan
Pada proses ini menggambarkan mekanisme pengelolaan jadwal dari setiap rungan yang dimiliki oleh UTS. Hal ini dapat membantu menunjang aktivitas kampus dengan cara mendata setiap jadwal penggunaan ruangan. Adapun gambaran dari proses tersebut adalah sebagai berikut :

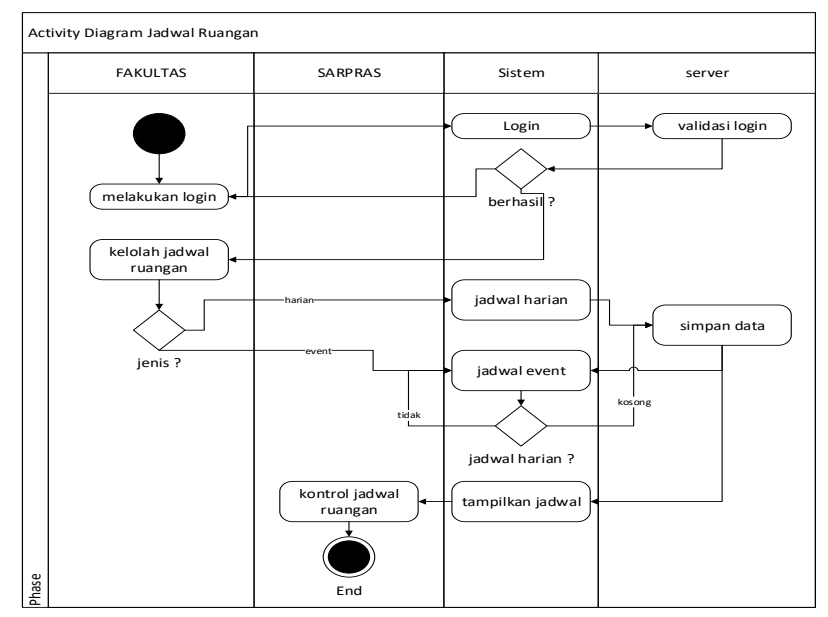

d) Pengadaan Inventaris

Pada proses pengadaan ini menggambarkan alur kerja dari pengadaan inventaris yang diajukan oleh biro SARPRAS yang selanjutnya akan menunggu persetujuan dari WAREK II sebelum melakukan pembelian inventaris. Alur kerja dari proses tersebut digambarkan seperti gambar dibawah ini :

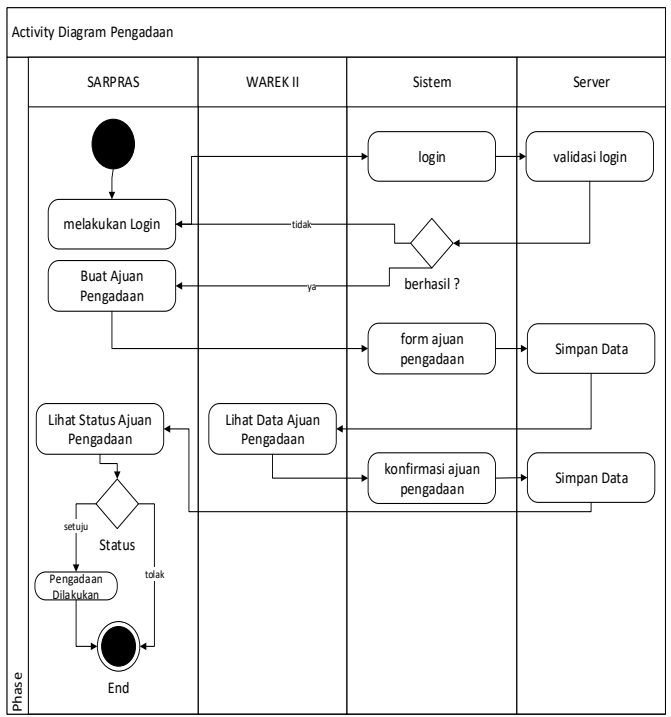

e) Peminjaman Inventaris

Proses peminjaman ini menggambarkan alur kerja dari peminjaman inventaris yang diajukan oleh civitas akademika uts pada umumnya seperti dosen, mahasiswa, ataupun staf - staf lain yang selanjutnya akan disetujui oleh biro SARPRAS sebelum objek yang 
dipinjam diberikan. Adapun alur kerja dari proses tersebut dapat dilihat pada gambar dibawah ini :

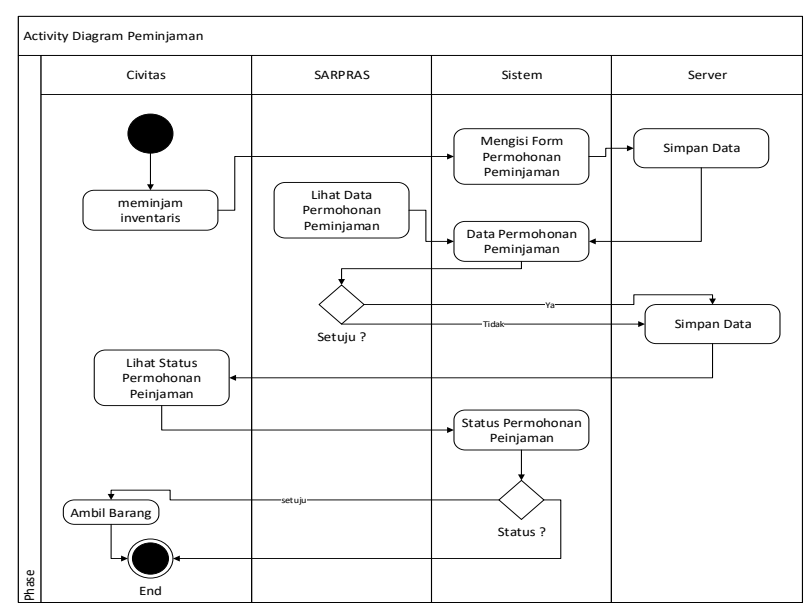

\section{3) Sequence Diagram}

a) Inventaris

Pada proses ini dapat digambarkan alur kerja dari proses pengelolaan inventaris seperti pada gambar dibawah ini :

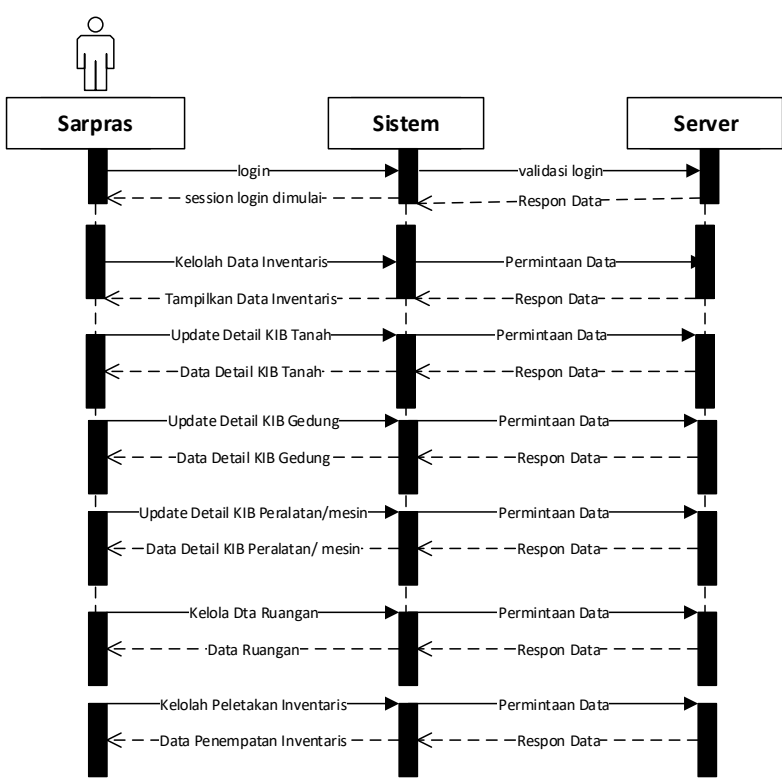

b) Mutasi

Pada proses mutasi ini, seperti yang telah dijelaskan pada pembahasan sebelumnya dapat digambarkan dengan sequence diagram yang menjelaskan secara terperinci bagaimana proses tersebut berjalan seperti pada gambar dibawah ini :

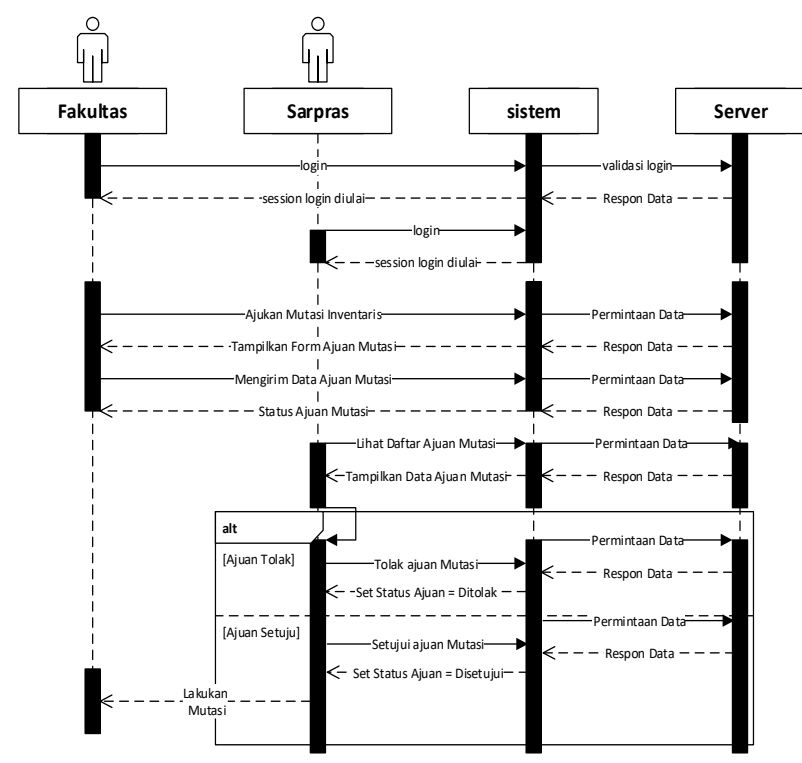

c) Jadwal ruangan

Untuk proses pengelolaan jadwal ruangan ini, dapat dilihat siklus dari aksi yang dilakukan seperti pada gambar dibawah ini :

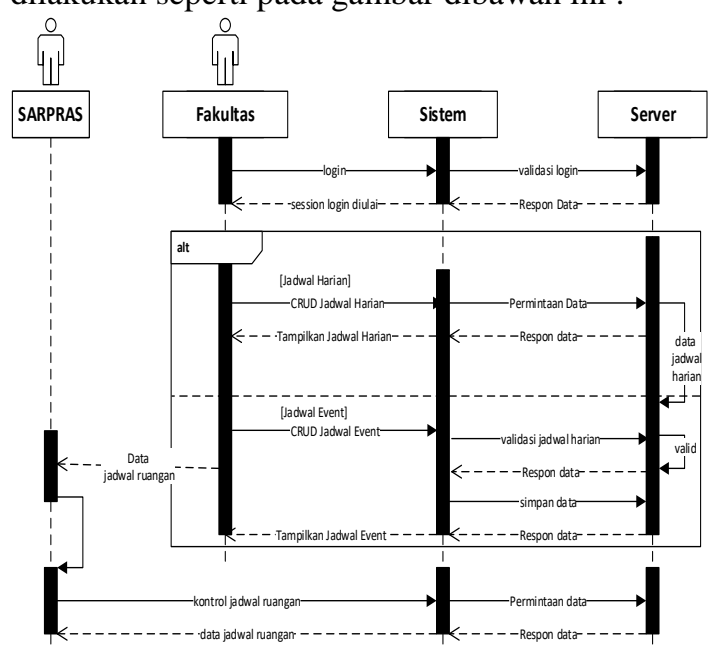

d) Pengadaan inventaris

Sequence diagram ini menggambarkan alur aktivitas pengadaan inventaris yang dilakukan oleh SARPRAS diajukan kepada WAREK II yang akan menyetujui pengadaan tersebut. adapun gambaran dari proses pengadaan seperti pada gmbar dibawah ini : 


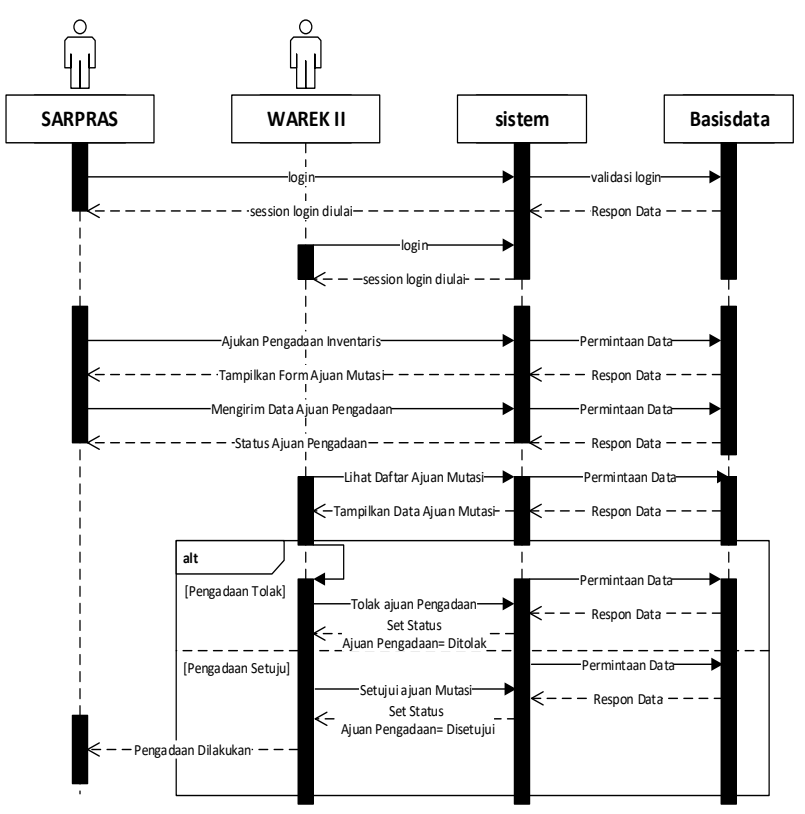

e) Peminjaman inventaris

Pada sequence diagram ini menggambarkan aktivitas peminjaman yang dilakukan oleh peminjam. Setiap permohonan peminjaman yang diajukan dapat disetujui ataupun ditolak oleh pihak SARPRAS selaku pengelolah inventaris. Berikut adalah gambaran dari aktivitas tersebut seperti gambar dibawah ini :

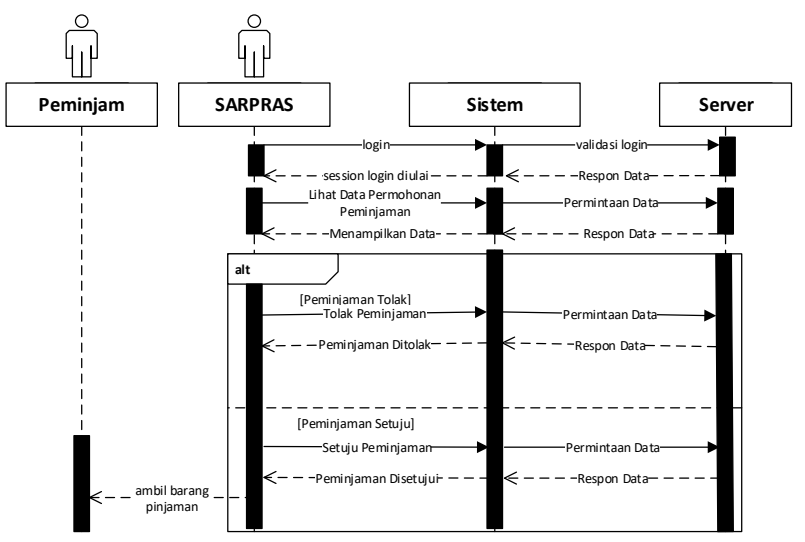

\section{4) Class Diagram}

Class diagram menggambarkan hubungan antar element sistem yang disebut class sebagai blue print dari sistem untuk menentukan objek objek yang dibutuhkan oleh sistem. Dengan class diagram ini akan mempermudah pada tahap coding sebagai referensi class yang akan di gunakan didalam sistem. Berikut adalah gambaran dari class diagram :
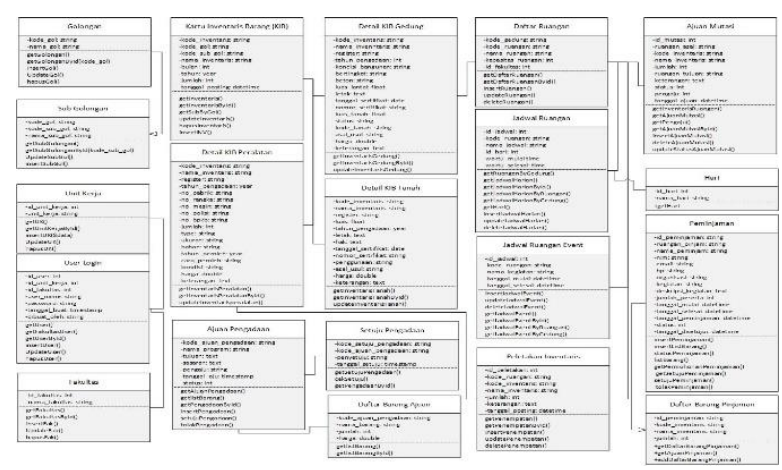

\section{b. User Interface}

\section{1) Halaman Depan}

Halaman depan ini dirancang untuk dapat diakses oleh siapa saja yang mengakses laman depan dari sistem. Pada halaman ini pengguna dapat melihat beberapa data inventaris seperti : data inventaris berupa ruangan dan jadwal ruangan, peminjaman inventaris, dan beberapa keterangan mengenai biro SARPRAS. Berikut adalah rancangan user interface halaman depan :

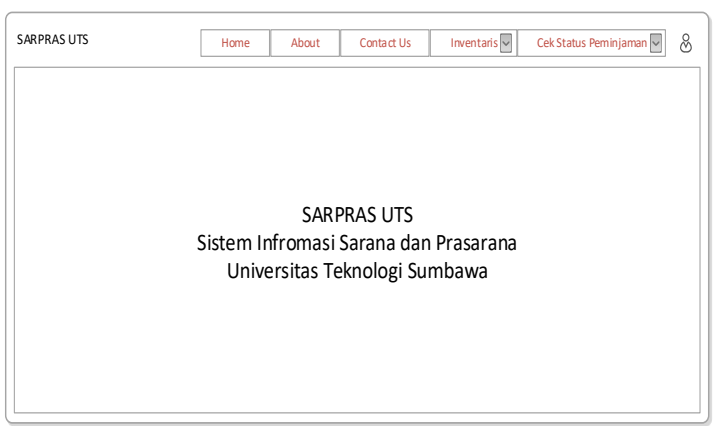

\section{2) Halaman Admin}

Halaman ini menampilkan data keseluruhan inventaris yang dimiliki oleh UTS. Pengguna dapat melakukan penambahan, pengeditan, dan penghapusan inventaris. Rancangan dari halaman ini dapat dilihat pada gambar berikut :

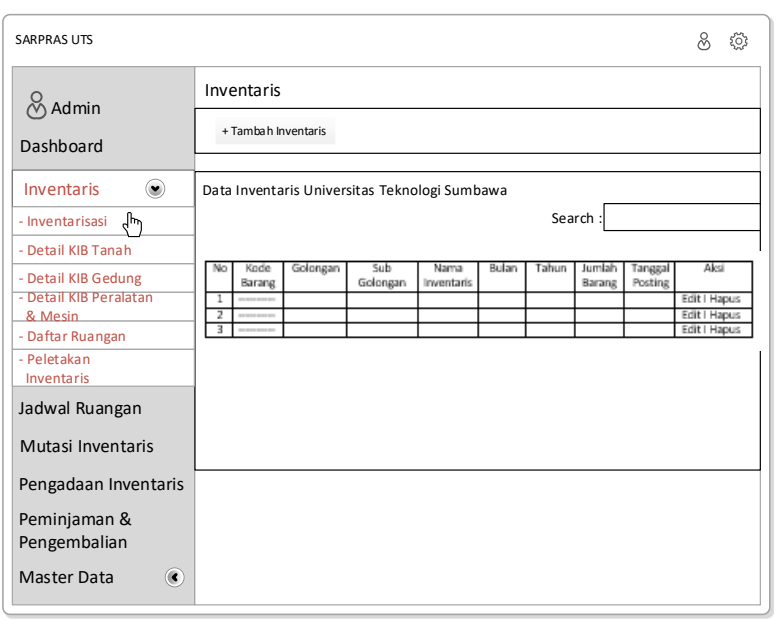




\section{Implementasi dan pengujian}

\section{a. Halaman Depan}

Halaman ini menampilkan halaman utama yang ditampilkan ketika mengakses sistem. Halaman ini tidak membutuhkan aksi login karena dapat diakses oleh public. Terdapat 3 bagian dari halaman ini yakni header, about, dan footer seperti gambar dibawah ini :

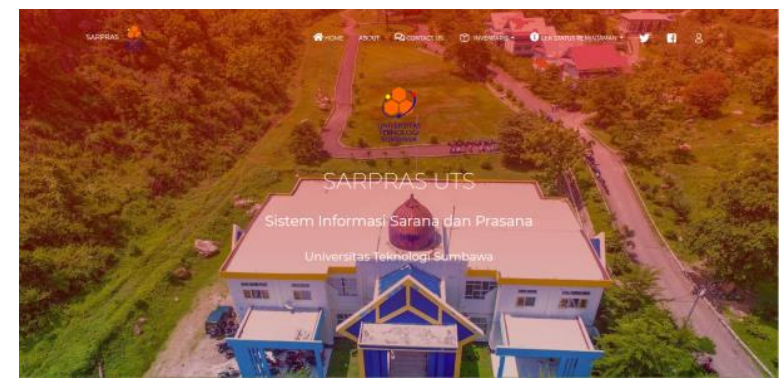

\begin{tabular}{|c|c|c|c|}
\hline Sub menu & Aksi & Pengamatan & $\begin{array}{c}\text { Kesimpu } \\
\text { lan }\end{array}$ \\
\hline $\begin{array}{l}\text { Daftar } \\
\text { Ruangan }\end{array}$ & Klik & Sesuai & Berhasil \\
\hline $\begin{array}{l}\text { Jadwal } \\
\text { Ruangan }\end{array}$ & Klik & Sesuai & Berhasil \\
\hline $\begin{array}{l}\text { Peminjaman } \\
\text { Inventaris }\end{array}$ & Klik & Sesuai & Berhasil \\
\hline $\begin{array}{l}\text { Cek Status } \\
\text { Peminjaman }\end{array}$ & $\begin{array}{l}\text { Input } \\
\text { Form }\end{array}$ & Sesuai & Berhasil \\
\hline Login & $\begin{array}{l}\text { Input } \\
\text { Form }\end{array}$ & Sesuai & Berhasil \\
\hline
\end{tabular}

\section{b. Halaman Admin}

Inventaris merupakan menu yang digunakan untuk mengelola data inventaris. Terdapat beberapa sub menu seperti gambar berikut :

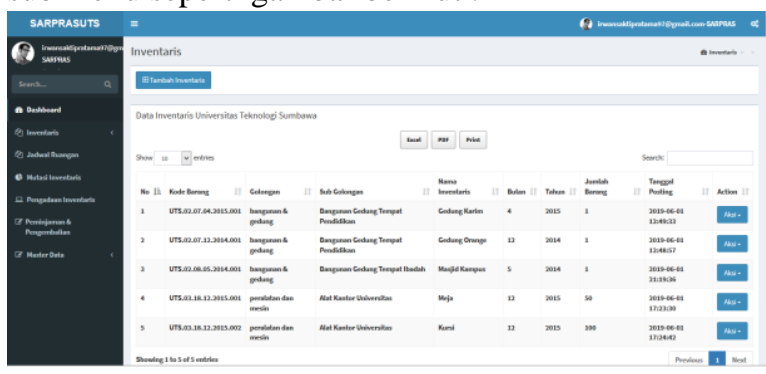

\begin{tabular}{|c|c|c|c|}
\hline Menu & Aksi & Pengamatan & $\begin{array}{c}\text { Kesimpu } \\
\text { lan }\end{array}$ \\
\hline Inventaris & Klik & Sesuai & Berhasil \\
\hline $\begin{array}{l}\text { Jadwal } \\
\text { Ruangan }\end{array}$ & Klik & Sesuai & Berhasil \\
\hline
\end{tabular}

\begin{tabular}{|c|c|c|c|}
\hline Menu & Aksi & Pengamatan & $\begin{array}{c}\text { Kesimpu } \\
\text { lan }\end{array}$ \\
\hline Mutasi & Klik & Sesuai & Berhasil \\
\hline Pengadaan & Klik & Sesuai & Berhasil \\
\hline Peminjaman & Klik & Sesuai & Berhasil \\
\hline
\end{tabular}

\section{Hasil Implementasi}

Dari hasil implementasi dan pengujian yang telah dijelaskan diatas, untuk mengetahui tingkat kepuasan pengguna terkait dengan sistem yang sedang dikembangkan penguji melakukan pengumpulan data dari beberapa sampel pengguna. Adapun pengumpulan data tersebut menggunakan kuisioner yang diberikan kepada beberapa sampel pengguna dari kalangan mahasiswa, dosen, sampai dengan pihak SARPRAS. Adapun data yang terkumpul dapat dilihat pada tabel berikut :

\begin{tabular}{|c|c|}
\hline Jenis responden & Jumlah \\
\hline Mahasiswa & 2 \\
\hline Dosen & 2 \\
\hline Peneliti sebelumnya & 1 \\
\hline Pihak SARPRAS & 1 \\
\hline Total responden & 6 \\
\hline
\end{tabular}

Dari total respondent diatas, dari masing masing jenis responden dikelompokkan menjadi 2 jenis pengguna yaitu halaman depan sama halaman admin. Adapun kelompok front pages yaitu halaman yang bisa diakses oleh seluruh pengguna tanpa memiliki hak akses kedalam sistem. Adapun yang mengakses halaman ini adalah seluruh responden pada tabel diatas. Sedangkan untuk kelompok back pages adalah halaman yang hanya bisa diakses oleh pengguna yang memiliki hak akses yang dalam hal ini hanya bisa dilakukan oleh responden dengan jenis pihak SARPRAS dan peneliti sebelumnya.

\section{a. Halaman Depan}

Berikut adalah rekap hasil penilaian dari responden mengenai sistem yang sedang dikembangkan dari total keseluruhan responden ada 6 (enam) yang dapat dilihat pada tabel dibawah ini : 


\begin{tabular}{|c|c|c|c|c|c|c|}
\hline $\mathrm{N}$ & Kriteria & $\begin{array}{c}\text { Sang } \\
\text { at } \\
\text { buru } \\
\mathrm{k}\end{array}$ & $\begin{array}{l}\text { Bur } \\
\text { uk }\end{array}$ & $\begin{array}{l}\text { Stand } \\
\text { ar }\end{array}$ & $\begin{array}{c}\text { Bai } \\
\mathrm{k}\end{array}$ & $\begin{array}{c}\text { Bai } \\
\text { k } \\
\text { sek } \\
\text { ali }\end{array}$ \\
\hline 1 & $\begin{array}{l}\text { Tampilan } \\
\text { Website }\end{array}$ & 0 & 0 & 0 & 6 & 0 \\
\hline 2 & $\begin{array}{l}\text { Kemudah } \\
\text { an } \\
\text { membaca } \\
\text { tulisan }\end{array}$ & 0 & 0 & 0 & 6 & 0 \\
\hline 3 & $\begin{array}{l}\text { Komposi } \\
\text { si warna } \\
\text { website }\end{array}$ & 0 & 0 & 3 & 3 & 0 \\
\hline 4 & $\begin{array}{l}\text { Struktur } \\
\text { menu } \\
\text { yang } \\
\text { disajikan }\end{array}$ & 0 & 0 & 2 & 4 & 0 \\
\hline 5 & $\begin{array}{l}\text { Konsiste } \\
\text { nsi } \\
\text { tampilan } \\
\text { layar } \\
\text { untuk } \\
\text { setiap } \\
\text { menu } \\
\end{array}$ & 0 & 0 & 0 & 6 & 0 \\
\hline 6 & $\begin{array}{l}\text { Kelengka } \\
\text { pan } \\
\text { informasi } \\
\text { yang } \\
\text { disajikan } \\
\text { mengenai } \\
\text { inventaris }\end{array}$ & 0 & 0 & 0 & 6 & 0 \\
\hline 7 & $\begin{array}{l}\text { Kemudah } \\
\text { an untuk } \\
\text { mendapat } \\
\text { kan } \\
\text { informasi } \\
\text { inventaris }\end{array}$ & 0 & 0 & 0 & 5 & 1 \\
\hline & Jumlah & 0 & 0 & 5 & 36 & 1 \\
\hline & ersentase & $0 \%$ & $0 \%$ & $12 \%$ & $\begin{array}{l}86 \\
\% \\
\end{array}$ & $2 \%$ \\
\hline
\end{tabular}

Persetase didapat dari rumus berikut : $\%=\frac{\text { jumlah tanggapan responden }}{\text { banyak responden } * \text { banyak pertanyaan }} \times 100 \%$ Dari tabel diatas, dapat dilihat bahwa dari tanggapan yang diberikan oleh responden lebih banyak menyatakan bahwa sistem yang sedang dikembangkan oleh peneliti baik dan layak untuk diimplementasikan dari sisi halaman depan.

\section{b. Halaman Admin}

Berikut adalah rekap hasil penilaian dari responden mengenai sistem yang sedang dikembangkan dari total keseluruhan responden yang dapat mengakses halaman admin ada 2 (dua) yang dapat dilihat pada tabel dibawah ini :

\begin{tabular}{|c|c|c|c|c|c|c|}
\hline $\begin{array}{l}\mathrm{N} \\
\mathrm{o}\end{array}$ & Kriteria & $\begin{array}{c}\text { Sang } \\
\text { at } \\
\text { buru } \\
\mathrm{k}\end{array}$ & $\begin{array}{c}\text { Bur } \\
\text { uk }\end{array}$ & $\begin{array}{c}\text { Stand } \\
\text { ar }\end{array}$ & $\begin{array}{c}\text { Bai } \\
k\end{array}$ & $\begin{array}{c}\text { Bai } \\
\text { k } \\
\text { seka } \\
\text { li }\end{array}$ \\
\hline 1 & $\begin{array}{l}\text { Kesesuai } \\
\text { an alur / } \\
\text { proses } \\
\text { pengelol } \\
\text { aan } \\
\text { inventari } \\
\text { s }\end{array}$ & 0 & 0 & 0 & 2 & 0 \\
\hline 2 & $\begin{array}{l}\text { Fungsi } \\
\text { yang } \\
\text { disediak } \\
\text { an dalam } \\
\text { mengelol } \\
\text { ah } \\
\text { inventari } \\
\text { s } \\
\end{array}$ & 0 & 0 & 0 & 2 & 0 \\
\hline 3 & $\begin{array}{l}\text { Notifikas } \\
\text { i yang } \\
\text { didapat } \\
\text { ketika } \\
\text { ada } \\
\text { transaksi } \\
\text { peminja } \\
\text { man } \\
\text { inventari } \\
\text { s } \\
\end{array}$ & 0 & 0 & 0 & 1 & 1 \\
\hline 4 & $\begin{array}{l}\text { Penggun } \\
\text { a yang } \\
\text { dapat } \\
\text { mengaks } \\
\text { es portal } \\
\text { pengelol } \\
\text { aan } \\
\text { inventari } \\
\text { s } \\
\end{array}$ & 0 & 0 & 0 & 1 & 1 \\
\hline 5 & $\begin{array}{l}\text { Tanggap } \\
\text { an biro } \\
\text { sarpras / } \\
\text { WAREK } \\
\text {-II } \\
\text { terkait } \\
\text { sistem } \\
\text { yang } \\
\text { dibuat } \\
\end{array}$ & 0 & 0 & 0 & 1 & 0 \\
\hline \multicolumn{2}{|c|}{ Jumlah } & 0 & 0 & 0 & 7 & 2 \\
\hline \multicolumn{2}{|c|}{ Persentase } & & & & $\begin{array}{l}70 \\
\% \\
\end{array}$ & $\begin{array}{l}20 \\
\% \\
\end{array}$ \\
\hline
\end{tabular}

Persetase didapat dari rumus berikut :

$\%=\frac{\text { jumlah tanggapan responden }}{\text { banyak responden } * \text { banyak pertanyaan }} \times 100 \%$

Dari tabel diatas, dapat dilihat bahwa dari tanggapan yang diberikan oleh responden lebih banyak menyatakan bahwa sistem yang sedang 
dikembangkan oleh peneliti baik dan layak untuk diimplementasikan dari sisi halaman admin.

\section{KESIMPULAN DAN SARAN}

Dari hasil penelitian tentang pengembangan sistem informasi sarana dan prasarana UTS berbasis web ini, dapat disimpulkan bahwa peneliti telah melakukan tahap analisis dan perancangan terhadap sistem yang kemudian menjadi landasan dalam membangun sistem tersebut. Dalam meerapkan hasil dari analisis dan perancangan tersebut menggunakan bahasa pemrograman PHP, JavaScript, Jquery, Framework CodeIgniter, serta database MySQL sebagai script dalam pembuatan sistem. Dari hasil kuisioner dapat disimpulkan bahwa sistem yang peneliti kembangkan tersebut dominan mendapat penilaian baik yang menandakan bahwa sistem tersebut layak untuk digunakan. Dengan demikian, sistem tersebut dapat membantu proses pengelolaan data inventaris dan transaksi peminjaman inventaris yang dikerjakan oleh biro SARPRAS UTS.

Adapun saran terhadap sistem ini untuk perbaikan atau pengembangan selanjutnya sebagai berikut :

a. Memperbaiki user interface menjadi lebih baik dan interaktif.

b. Menambahkan fitur notifikasi realtime pada sistem.

c. Menyempurnakan proses peminjaman dan pengembalian.

\section{DAFTAR PUSTAKA}

[1]Juliani, Eva. 2017. Sistem Informasi Pengelolaan Sarana Dan Prasarana di Universitas Teknologi Sumbawa. Skripsi. Tidak Diterbitkan. Fakultas Teknologi Informatika. Universitas Teknologi Sumbawa: Sumbawa.

[2]Poetro, Rotstaland Dito Soeharto. 2017. Sistem Informasi Prasarana Berbasis Web Studi

Kasus SD Negeri 1 Gatak Delangu. Skripsi. Tidak Diterbitkan. Fakultas Komunik asi dan Informatika. Universitas Muhammadiyah Surakarta: Surakarta.

[3]Sholikhin, Akhmad \& Berliana Kusuma Riasti. 2013. Pembangunan Sistem Informasi Inventarisasi Sekolah Pada Dinas Pendidikan Kabupaten Rembang Berbasis Web. Indonesian Jurnal on Networking and Security (IJNS).2(2):50-57.

[4]O’Brein, James A. 2005. Pengantar Sistem Informasi. Jakarta: Salemba Empat.

[5]Megasari, Rika. 2014. Peningkatan Pengelolaan Sarana Dan Prasarana Pendidikan Untuk
Meningkatan Kualitas Pembelajaran Di Smpn 5 Bukittinggi. Administrasi Pendidikan. 2(1): 637 831.

[6]S, Rosa A., \& M. Shalahuddin. 2018. Rekayasa Perangkat Lunak Tersteuktur dan Berorientasi Objek. Bandung: Informatika.

[7]Ladjamudin, Al Bahra Bin. 2006. Analisis dan Desain Sistem Informasi. Yogyakarta: Graha Ilmu.

[8]Pressman, Roger S. 2015. Rekayasa Perangkat Lunak Pendekatan Praktisi. Yogyakarta: Andi.

[9]Arief, M.Rudianto. 2011. Pemrograman Web Dinamis Menggunakan PHP dan Mysql. Yogyakarta: Andi. 